\title{
Toxicity and Toxin Composition of Microcystis aeruginosa from Wangsong Reservoir
}

\section{Esterhuizen-Londt, Maranda}

2018-10

Esterhuizen-Londt , M , Baik , S , Kwon , K-S , Ha , M-H , Oh , H-M \& Pflugmacher , S 2018 ,

' Toxicity and Toxin Composition of Microcystis aeruginosa from Wangsong Reservoir ',

Toxicology and environmental health sciences, vol. 10 , no. 3 , pp. 179-185 . https://doi.org/10.1007/s13530-018-03

http://hdl.handle.net/10138/307911

https://doi.org/10.1007/s13530-018-0362-4

acceptedVersion

Downloaded from Helda, University of Helsinki institutional repository.

This is an electronic reprint of the original article.

This reprint may differ from the original in pagination and typographic detail.

Please cite the original version. 
Running title: Wangsong Microcystis aeruginosa toxicity

4

Maranda Esterhuizen-Londt ${ }^{1,6}$, Seungyun Baik ${ }^{2}$, Kyu-Sang Kwon ${ }^{3}$, Mi-Hee Ha ${ }^{1,4}$, Hee-Mock

$6 \mathrm{Oh}^{5}$, Stephan Pflugmacher ${ }^{1,2,6,7^{*}}$

7

$8{ }^{1}$ Technische Universität Berlin, Department of Ecotoxicological Impact Research and Ecotoxicology,

9 Ernst-Reuter-Platz 1; 10587 Berlin, Germany

$10{ }^{2}$ Korea Institute of Science and Technology Europe (KIST), Joint Laboratory of Applied Ecotoxicology,

11 Campus 7.1, Saarbrücken, Germany

$12{ }^{3}$ Korea Institute of Science and Technology (KIST), Centre for Water Resource Cycle Research, 39-1

13 Hawarangno 14-gil 5, Seongbuk-gu, Seoul, 136-791, Republic of Korea

$14{ }^{4}$ Evonik Resource Efficiency GmbH, Rodenbacher Chaussee 4, 63457 Hanau-Wolfgang, Germany

$15{ }^{5}$ Korean Research Institute of Bioscience \& Biotechnology (KRIBB), 125 Gwahak-ro, Yuseong-gu,

16 Daejeon 306-809, Republic of Korea

$17{ }^{6}$ Current affiliation: Ecosystems and Environmental Research Programme, Faculty of Biological and 18 Environmental Sciences, University of Helsinki, Niemenkatu 73, 15140 Lahti, Finland

$19{ }^{7}$ Helsinki Institute of Sustainability Science (HELSUS), University of Helsinki, Fabianinkatu 33, 00014 20 Helsinki

* Corresponding author

23 Prof Dr S. Pflugmacher

24 Ecosystems and Environmental Research Programme, Faculty of Biological and Environmental

25 Sciences, University of Helsinki, Niemenkatu 73, 15140 Lahti, Finland

Tel: +358 503167329; Email: stephan.pflugmacher@helsinki.fi 
27 Abstract

Objective

The increasing world population, resulting in increased anthropogenic water pollution, is negatively impacting the limited available water resources. In South Korea, this similarly affects the water quality of reservoirs. As water is a basic necessity for life, water quality monitoring is essential but typically does not include toxicity testing. However, as toxic bloom event frequencies are increasing, this previously neglected aspect becomes pertinent. Therefore, in the present study, the toxin composition and toxicity of a Microcystis aeruginosa strain isolated from a persistent bloom in lake Wangsong, South Korea, was investigated.

Methods

A combination of bioassays and chemical analysis was used for this purpose. The bioassay species included terrestrial and aquatic plants, an alga, a rotifer, a tubificid annelid, and crustaceans, representing various trophic levels.

\section{Results}

The strain was found to produce microcystin-LR, -RR, and YR, as well as $\beta$ - $N$-methylaminoL-alanine. The bioassays indicated that the primary producers were less sensitive to the crude extract.

\section{Conclusion}

The presence of absence of a visible cyanobacterial bloom is also not an indication of the toxins that may be present in the afflicted waters, and thus does not predict exposure risk. Similarly, the presence and absence of toxins and mixtures thereof does not indicate the ecological effect. Therefore, it would be advantages to include toxicity testing into routine water testing regimes to better understand the impact of harmful algal blooms.

\section{Keywords:}

2 Cyanobacteria, microcystin congeners, bioassays, toxicity 
54 Eutrophication, accepted as the main reason for the outbreak of potentially toxic cyanobacterial blooms $^{1}$, is also one of the principal driving factors for bloom formation in South $\mathrm{Korea}^{2}$ where, in general, the four major rivers Han, Geum, Nakdong, and Yeongsan, are most heavily affected $^{3-5}$. As they also function as potable water sources and are used for recreational purposes, the water quality is a major focus in these rivers and the lakes they collect into ${ }^{6}$. Typically, lake water quality and the trophic state thereof are evaluated using a variety of parameters including $\mathrm{pH}$, total organic carbon, chlorophyll-a, total phosphorus, and turbidity ${ }^{7}$, but not toxin content or toxicity. In terms of toxin content, microcystin concentrations of 0.057 $\mu \mathrm{g} \mathrm{L}^{-1}$ up to $2612 \mu \mathrm{g} \mathrm{L}^{-1}$ have been detected in these different river systems ${ }^{5,8}$, however, to date toxicity testing seems to have been neglected. Aside from microcystins (MCs), anatoxin-a has been detected in the Daecheong reservoir ${ }^{9}$, yet toxin characterization data for the Wangsong lake, a major urban reservoir, is lacking.

The Wangsong reservoir, a shallow eutrophic reservoir located in Uiwang City, was built to secure a stable water resource for the area and is classified as a water supply, as a recreational feature, and is used for industrial purposes, as well as agricultural and landscape irrigation ${ }^{10,11}$. The dam was also constructed as a flood control mechanism and for hydroelectric power generation. Due to ongoing expansion and housing projects, pollution of the Wangsong reservoir has steadily increased, accompanied by cyanobacterial bloom formation ${ }^{7}$. Hence, great attention has been paid to water quantity and quality problems of the reservoir. Cyanotoxins constitute a threat to the health of humans in contact with contaminated waters since they have toxic effects in living organisms ${ }^{12}$. Microcystis aeruginosa is the most common bloom-forming cyanobacterial species in freshwaters and has the ability to produce secondary metabolites such as the potent hepatotoxins, especially $\mathrm{MCs}^{13}$. To date, the dominant cyanobacterial genera which occur in the four main river systems in South Korea include 
78 Microcystis, Anabaena, and Oscillatoria ${ }^{3,5,8,14}$, with microcystin-LR, -RR, and -YR as the most

79 frequently detected MC isomers ${ }^{3}$.

80 Most of the available studies describe the toxic effects of single MCs in aquatic organisms such

81 as fish species, cladocerans, and mussels ${ }^{15-20}$. Only a few studies include exposure of

82 phytoplankton and macrophytes to crude extracts of $M$. aeruginosa, also evaluating the

83 oxidative stress responses, which resemble a closer approach to actual environmental

84 scenarios $^{21-24}$. Information regarding how water quality affects primary producers will

85 furthermore shed light on how higher trophic levels will be affected.

86 The aim of the present study was to elucidate the toxin composition of the M. aeruginosa strain

87 isolated from the Wangsong reservoir, South Korea. Besides the toxin composition, the

88 potential toxicity was evaluated using different bioassay systems, thereby assessing the

89 potential health risk at various trophic levels. 
92 The seasonal variation of Microcystis species in South Korean reservoirs has previously been 93 monitored $^{11,25}$.

94

95 In the aqueous cell-free crude extract of the M. aeruginosa strain, three different microcystin congeners in total, namely MC-LR, MC-RR, and MC-YR, were detected (Fig. 1). The highest concentrations were detected for MC-LR $\left(176.35 \mu \mathrm{g} \mathrm{g}^{-1}\right)$ followed by MC-RR $\left(50.27 \mu \mathrm{g} \mathrm{g}^{-1}\right)$ and the lowest concentration for MC-YR $\left(9.25 \mu \mathrm{g} \mathrm{g}^{-1}\right) . \beta-N$-methylamino-L-alanine (BMAA) was detected and quantified amounting to an average concentration of $0.906 \pm 0.016 \mu \mathrm{g} \mathrm{g}^{-1}$. In the extract, neither anatoxin-a nor cylindrospermopsin was detected by the employed quantitative analysis methods.

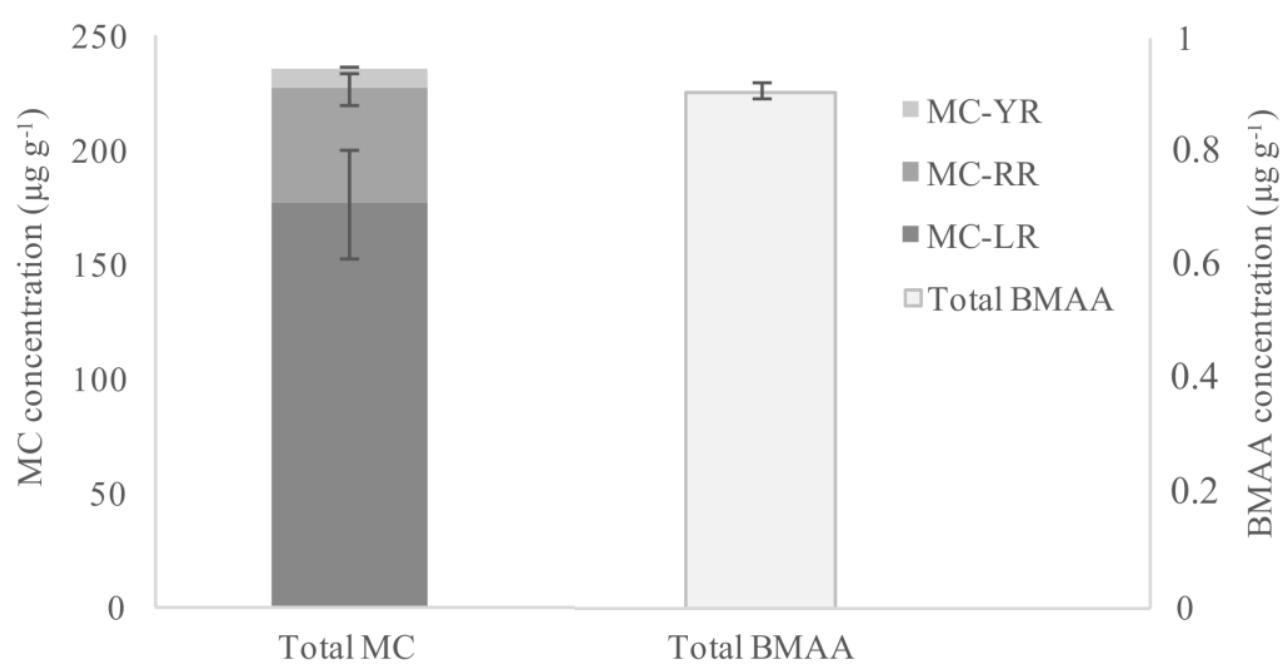

104 Figure 1: Cyanobacterial toxin composition of the M. aeruginosa $\mathrm{KW}$ strain isolated 105 from Wangsong reservoir (South Korea). Data represent mean toxin concentration \pm 106 standard deviation $(\mathrm{n}=4)$ 
109 The toxicity of the crude extract in various dilutions was tested using various commercially

110 available TOXKITs in combination with non-commercially available bioassays such as the

111 toxicity towards T. tubifex and the oxidative stress status in aquatic macrophytes.

112 Using the commercial TOXKIT bioassays (Table 1), the aqueous crude extract resulted in a

113 relatively high toxicity response using the THAMNOTOX-F $\mathrm{F}^{\mathrm{TM}}$ kit with an LC50 amounting to

$1140.1 \mu \mathrm{g} \mathrm{L}^{-1}$ followed by the DAPHTOX pulex kit with an EC50 of $1.1 \mu \mathrm{g} \mathrm{L}^{-1}$ and therefore 10115 fold less sensitive compared to the THAMNOTOX-F ${ }^{\mathrm{TM}}$ kit. The $24-\mathrm{h} \mathrm{LC}_{50}$ for the strain 116 obtained using the THAMNOTOX- $\mathrm{F}^{\mathrm{TM}}$ kit corresponded to previously reported toxicities for 117 M. aeruginosa isolated from Hungary, Germany and Brazil ${ }^{26}$. The toxicity of the extract was 118 much 8.7 times higher than the previously reported toxicity of an M. aeruginosa extract with 119 Daphnia pulex (48-h LC $\left.509.6 \mu \mathrm{g} \mathrm{ml}^{-1}\right)^{27}$. The ALGALTOX (EC50 of $\left.3.7 \pm 1.2 \mu \mathrm{g} \mathrm{ml}{ }^{-1}\right)$ and 120 PHYTOTOX kits (average IC50 of $3.9 \mu \mathrm{g} \mathrm{ml}^{-1}$ ) demonstrated the lowest responses with the 121 crude extract exposure, demonstrating lower sensitivities for primary producers. Previously, an $122 \mathrm{IC}_{50}$ of $3 \mathrm{mg} \mathrm{ml}^{-1}$ was reported for M. aeruginosa using the Blue-green Sinapis alba test ${ }^{28}$, 123 approximately a 1000-fold higher concentration. Using the TUBIFEX toxicity test the 124 sensitivity towards the crude extract was similar to that obtained with the DAPHTOX pulex kit, 125 interestingly as both as primary consumers. 
126 Table 1: Determination of $\mathrm{LC}_{50}, \mathrm{EC}_{50}$ and $\mathrm{IC}_{50}$ using various bioassays, commercially available ones as 127 well as others.

\begin{tabular}{|c|c|c|c|c|}
\hline Bioassay & Test organisms & $\begin{array}{l}\text { Trophic } \\
\text { level }\end{array}$ & $\begin{array}{l}\text { Test outcome } \\
\text { (LC } \mathrm{C}_{50}, \mathrm{EC}_{50} \text {, } \\
\left.\text { IC }_{50}{ }^{*}\right)\end{array}$ & 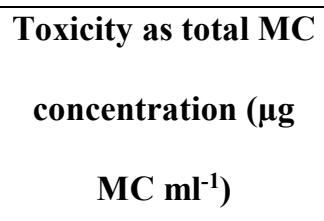 \\
\hline THAMNOTOX-FTM & $\begin{array}{c}\text { Thamnocephalus } \\
\text { platyurus }\end{array}$ & $\begin{array}{l}\text { Primary } \\
\text { consumer }\end{array}$ & 24-h LC 50 & $0.1 \pm 0.2$ \\
\hline ROTOTOX-F & $\begin{array}{l}\text { Brachionus } \\
\text { calyciflorus }\end{array}$ & $\begin{array}{l}\text { Primary } \\
\text { consumer }\end{array}$ & 24-h EC 50 & $6.5 \pm 1.2$ \\
\hline DAPHTOX pulex & Daphnia pulex & $\begin{array}{l}\text { Primary } \\
\text { consumer }\end{array}$ & 24-h EC ${ }_{50}$ & $1.1 \pm 0.5$ \\
\hline TUBIFEX TOX & Tubifex tubifex & Detritivore & 24-h $\mathrm{EC}_{50}$ & $1.5 \pm 0.7$ \\
\hline ALGALTOX & $\begin{array}{l}\text { Pseudokirchneriella } \\
\text { subcapitata }\end{array}$ & $\begin{array}{l}\text { Primary } \\
\text { producer }\end{array}$ & 72-h EC 50 & $3.7 \pm 1.2$ \\
\hline РНYТОТОХ & $\begin{array}{c}\text { Sorghum saccharatum } \\
\text { Sinapis alba }\end{array}$ & $\begin{array}{l}\text { Primary } \\
\text { producers }\end{array}$ & $\begin{array}{l}\text { 72-h IC } 50 \\
\text { 72-h IC } 50\end{array}$ & $\begin{array}{l}3.4 \pm 0.5 \\
4.4 \pm 0.9\end{array}$ \\
\hline & Lepidium sativum & & 72-h IC 50 & $3.9 \pm 1.2$ \\
\hline
\end{tabular}

$* \mathrm{LC}_{50}=$ lethal concentration, $\mathrm{EC}_{50}=$ effect concentration, $\mathrm{IC}_{50}=$ inhibitory concentration

130 Morphological changes monitored in three different aquatic macrophytes exposed to the bloom

131 extract showed severe changes only in P. perfoliatus for which all plants became chlorotic 132 within the exposure time of 14 days (Table 2). C. demersum, as well as L. sessilifora, did not 133 show any visible effects; however, in L. sessiliflora the leaves seemed to crinkle more than 134 compared to the control (Table 2). 
135 Table 2: Altered morphology of macrophytes exposed to cyanobacterial cell-free crude extract 136 containing MCs at a concentration of $50 \mu \mathrm{g} \mathrm{L}^{-1}$ for 14 days





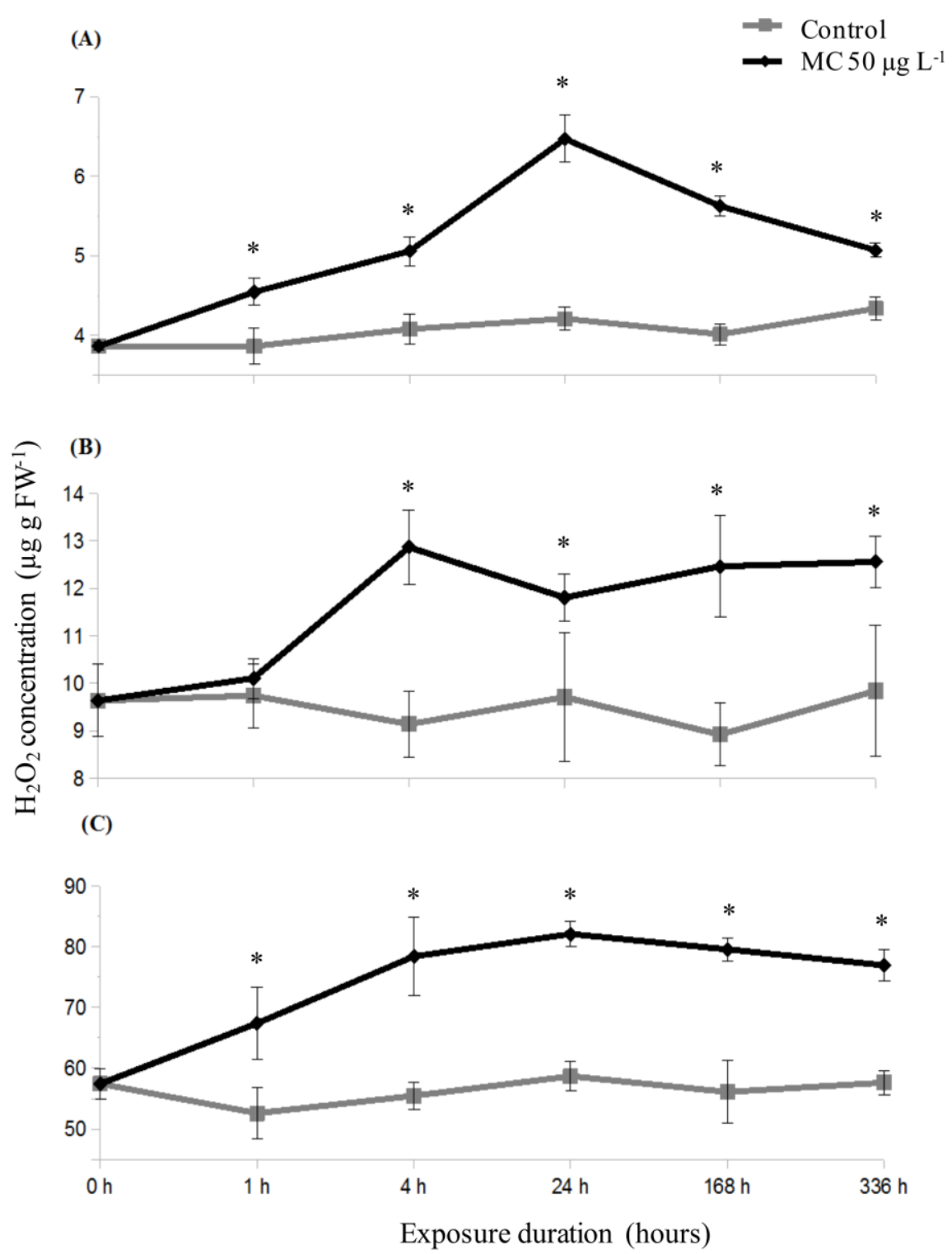

139 Figure 2: Oxidative stress response monitored as changes in cellular $\mathrm{H}_{2} \mathrm{O}_{2}$ level in three

140 submerged macrophytes: C. demersum (A), L. sessiliflora $(\mathbf{B})$ and $P$.perfoliatus $(\mathbf{C})$ during

141 14-day exposure to a cyanobacterial cell-free crude extract containing $50 \mu \mathrm{g} \mathrm{L}^{-1}$ total MCs.

142 Data represent average $\mathrm{H}_{2} \mathrm{O}_{2}$ content \pm standard deviation $(\mathrm{n}=3) ;$ * denotes statistical

143 significance compared to the control $(\mathrm{p}>0.05)$

145 Significantly enhanced $\mathrm{H}_{2} \mathrm{O}_{2}$ levels compared to the control $(\mathrm{p}<0.05$; Fig. 2$)$ were evident for $146 C$. demersum and $P$. perfoliatus from the onset of exposure, however, the $\mathrm{H}_{2} \mathrm{O}_{2}$ content only increased for L. sessiliflora after 1 hour of exposure ( $p>0.05$; Fig. 2). For $C$. demersum and $P$. perfoliatus, the $\mathrm{H}_{2} \mathrm{O}_{2}$ content increased until 24 hours of exposure, indicating that the level of 
reactive oxygen species started to exceed the anti-oxidative capacity of the plants, where after

150 the $\mathrm{H}_{2} \mathrm{O}_{2}$ decreased, hinting at recovery. However, after 14 days, the normal $\mathrm{H}_{2} \mathrm{O}_{2}$ level, as seen

151 in the control, was not regained.

152 The aquatic macrophytes indeed showed adverse effects due to exposure the crude extract 153 containing a concertation of $50 \mu \mathrm{g} \mathrm{ml}^{-1}$ total MC. However, compared to the PHYTOTOX kits, 154 for which an average IC50 of $3.9 \mu \mathrm{g} \mathrm{ml}^{-1}$ was achieved, the aquatic macrophytes seemed less 155 sensitive as plant death was only observed in exposures with $P$. perfoliatus albeit the12.8-fold 156 higher concentration.

157 The results show the importance of testing toxicity at various trophic levels as the different 158 organism displayed different sensitives. In the present study, primary producers were found to 159 be less sensitive to a crude extract containing MC, compared to primary consumers and 160 detritivores such as for example the T. platyurus, T. tubifex, and D. pulex. In general, the strain 161 was found to be in some cases equally toxic (as seen with $T$. platyurus) and in others more toxic 162 (as seen with D. pulex) compared to blooms reported elsewhere. The study illustrates that 163 toxicity testing is an essential test parameter that should be considered together with routine 164 water quality evaluations.

\section{Material \& Methods}

\subsection{Cyanobacterial Strain and Crude Extract}

168 Samples were collected from the Wangsong reservoir, South Korea, during a bloom event 169 between July and October in 2007. The bloom consisted mainly of M. aeruginosa with a minor 170 proportion of other cyanobacteria such as Anabaena and Oscillatoria. The strain, M. aeruginosa $171 \mathrm{KW}$, was isolated from the bloom material and cultivated in $1 \mathrm{~L}$ Erlenmeyer flasks containing $172500 \mathrm{~mL}$ of BG 11 medium $^{29}$ under 30-40 mmol photon $\mathrm{m}^{-2} \mathrm{~s}^{-1}$ with a photoperiod of 14:10 h 173 photoperiod at $22 \pm 1^{\circ} \mathrm{C}$. Culture purity was evaluated microscopically using brightfield. The 174 crude extracts were prepared as described by Romero-Oliva et al. ${ }^{30}$. 
176 Microcystin congener (MC-LR, -RR, and -YR) determination and quantification were 177 performed as detailed in Romero-Oliva et al. ${ }^{30}$. Calibrations were linear $\left(\mathrm{R}^{2}=0.999\right)$ between 1785 and $500 \mu \mathrm{g} \mathrm{L}^{-1}$. Limit of detection (LOD) was set at $1 \mathrm{ng} \mathrm{mL} \mathrm{m}^{-1}$ (signal to noise $\mathrm{S} / \mathrm{N}>3$ ) and 179 limit of quantification at $5 \mathrm{ng} \mathrm{mL}^{-1}(\mathrm{~S} / \mathrm{N}>5)$ for all MCs congeners.

180 Anatoxin-a chromatographic detection and quantification was performed as detailed in Ha et 181 al. ${ }^{31}$. Calibrations were linear $\left(\mathrm{R}^{2}=0.999\right)$ between 5 and $250 \mu \mathrm{g} \mathrm{L}{ }^{-1}$. LOD and LOQ were 1 182 $(\mathrm{S} / \mathrm{N}>3)$ and $5 \mu \mathrm{g} \mathrm{L}{ }^{-1}(\mathrm{~S} / \mathrm{N}>5)$, respectively.

BMAA was detected and quantified after derivatization using a Phenomenex EZ:Faast kit as 184 detailed by Esterhuizen-Londt et al. ${ }^{32}$. Calibrations were linear between 0.1 and $1000 \mu \mathrm{g} \mathrm{L}^{-1}$, 185 with the limit of detection set at $100 \mathrm{fg}$ on column $(\mathrm{S} / \mathrm{N}>3)$ and the limit of quantification set 186 at $1 \mathrm{pg}$ on column $(\mathrm{S} / \mathrm{N}>5)$.

187 Chromatographic detection and quantification of CYN were performed as detailed by 188 Esterhuizen-Londt et al. ${ }^{33}$. Calibrations for this method were linear $\left(\mathrm{R}^{2}=0.998\right)$ between 0.01 189 and $100 \mu \mathrm{g} \mathrm{L}^{-1}$.

\subsection{Toxicity Assays}

191 All TOXKITS were purchased from Microbiotests, Belgium. Producer protocols were strictly 192 followed, including verification of culture media, $\mathrm{pH}$, and the quality of the controls. The 193 dilutions of the crude extract, were prepared in the appropriate exposure media in final 194 concentrations of $100,20,4,0.8,0.16$ and $0.03 \mathrm{mg} \mathrm{dw}$ biomass $\mathrm{mL}^{-1}$, i.e. $99.00,19.80,3.96$, $1950.79,0.16$, and $0.03 \mu \mathrm{g}$ total $\mathrm{MC} \mathrm{L}^{-1}$.

196 THAMNOTOXKIT F ${ }^{\mathrm{TM}}$, using the fairy shrimp Thamnocephalus platyurus instar II-III larvae 197 was used for the first investigation. The test was carried out in six replicates of 30 animals each 198 incubated with the various crude extract dilutions at $25^{\circ} \mathrm{C}$ in the dark for $24 \mathrm{~h}$. Dead larvae were 199 counted, and the $\%$ mortality was calculated as well as the $24 \mathrm{~h} \mathrm{LC} 50$ using standard methods ${ }^{34}$. 
200 For the ROTOXKIT F, juveniles of the rotifer Brachionus calyciflorus were utilized for the 201 acute $24 \mathrm{~h}$ toxicity test, with 30 animals per test concentration in six replicates. The plates were 202 incubated at $25^{\circ} \mathrm{C}$ in darkness. After $24 \mathrm{~h}$, the dead animals were counted, and the \% mortality, 203 as well as the LC50, was calculated ${ }^{35}$.

204 For the DAPHTOXKIT pulex, Daphnia pulex neonates were hatched from ephippia four days 205 before the start of the tests. The test was with 50 neonates per test concentration in replicates 206 of six. Hatching was initiated in Petri dishes with $15 \mathrm{~mL}$ standard freshwater at $20^{\circ} \mathrm{C}$ under 207 continuous illumination with $8000 \mathrm{lux}$, at $25^{\circ} \mathrm{C}$ in darkness. After $24 \mathrm{~h}$, deceased animals were 208 counted, and the \% mortality, as well as the LC50, was calculated.

209 For all of the kits mentioned above, the tests were only valid with mortalities in controls being 210 less than $10 \%$. Positive controls were performed using potassium dichromate $\left(\mathrm{K}_{2} \mathrm{Cr}_{2} \mathrm{O}_{7}\right)(1000$ 211 ppm stock solution) diluted to a series of $1.8,1.0,0.56,0.32$, and $0.18 \mathrm{mg} \mathrm{L}^{-1}$.

212 TUBIFEX Toxicity TEST utilizes the oligochaete Tubifex tubifex for toxicity testing ${ }^{36}$. The test 213 was performed in small glass beakers with 50 animals per test concentration in replicates of 214 ten. Mortality of the oligochaete was evaluated microscopically after the exposure time of 24 215 h.

216 The ALGALTOXKIT used Selenastrum capricornutum (renamed as Pseudokirchneriella 217 subcapitata) in a $72 \mathrm{~h}$ algal growth test. Optical density, as a measure of growth, was measured 218 using a spectrophotometer at $670 \mathrm{~nm}$ strictly according to the protocol.

219 The PHYTOTESTKIT employed seeds of three different terrestrial plants Sorghum 220 saccharatum (monocotyledon), Lepidium sativum and Sinapis alba (dicotyledons) to test for 221 toxic effects, i.e. effects on germination and early development. The tests were performed in 222 three replicates in a climate chamber for three days at $25^{\circ} \mathrm{C}$ in the dark. For the germination, 223 the germinated seeds were counted and values compared to those of controls as a measure of 224 toxicity. 
MORPHOLOGICAL CHANGES of MACROPHYTES were determined using three different

226 aquatic macrophytes, namely Ceratophyllum demersum, Limnophila sessilifora, and

227 Potamogeton perfoliatus. Macrophytes were exposed to the crude extract at a biomass density

228 of $10 \mathrm{mg} \mathrm{fw} \mathrm{L}^{-1}$ amounting to $22.5 \mu \mathrm{g} \mathrm{MC-LR} \mathrm{L}{ }^{-1}, 24.7 \mu \mathrm{g}-\mathrm{RR} \mathrm{L}^{-1}$ and $2.8 \mu \mathrm{g}-\mathrm{YR} \mathrm{L}^{-1}\left(50 \mu \mathrm{g} \mathrm{L} \mathrm{L}^{-}\right.$

$229{ }^{1}$ in total). Morphological changes between the controls and the exposed plants were visibly 230 assessed after 14 days.

231 OXIDATIVE STRESS RESPONSES of MACROPHYTE were measured in C. demersum in a $23224 \mathrm{~h}$ static renewal exposure experiment. Plant material (3 g wet weight) was exposed in 100 $233 \mathrm{~mL}$ medium containing the crude extract $\left(50 \pm 0.8 \mu \mathrm{g} \mathrm{L}^{-1}\right.$ total MCs, as before $)$ in replicates of 234 five in parallel with an unexposed control. The level of cell internal $\mathrm{H}_{2} \mathrm{O}_{2}$ as a marker for 235 oxidative stress was colorimetrically determined according to the method of Jana and 236 Choudhuri ${ }^{37}$.

$237 \quad$ 3.4.Data analyses

238 The TOXKIT assay effect levels were calculated using the Microtox statistical analysis 239 software program, which calculates effect concentrations (EC1, EC10, EC20, and EC50) and 240 associated 95\% confidence intervals for 15 and 30-min exposure periods. Statistical significant 241 differences and Pearson Correlation coefficients were calculated using Statistica software. 242 Concentration-response curves were evaluated using Probit analysis ${ }^{34}$, and the $50 \%$-effective 243 concentrations $\left(\mathrm{LC}_{50}, \mathrm{EC}_{50}\right.$, or $\left.\mathrm{IC}_{50}\right)$ for the respective assay. The differences and statistical 244 significance were evaluated using ANOVA, followed by Duncan's post-hoc test. Statistical 245 significance was considered at $\mathrm{p}<0.05$.

\section{4. Conclusion}

247 The presence of absence of a visible cyanobacterial bloom is also not an indication of the toxins 248 that may be present in the afflicted waters and thus does not predict exposure risk. Similarly, 249 the presence and absence of toxins and mixtures thereof do not indicate the ecological effect. 
Therefore, it would be advantages to include toxicity testing into routine water testing regimes

251 to better understand the impact of harmful algal blooms.

\section{References}

1. Scholz, S. N., Esterhuizen-Londt, M. \& Pflugmacher, S. Rise of toxic cyanobacterial blooms in temperate freshwater lakes: causes, correlations and possible countermeasures. Toxicological \& Environmental Chemistry 99, 543-577 (2017).

2. Park, S. B. Algal blooms hit South Korean rivers. Nature doi:10.1038/nature.2012.11221 (2012).

3. Park, H. D., Kim, B., Kim, E. \& Okino, T. Hepatotoxic microcystins and neurotoxic anatoxin-a in cyanobacterial blooms from Korean lakes. Environmental Toxicology and Water Quality 13, 225-234 (1998).

4. Joung, S.-H., Oh, H.-M., Ko, S.-R. \& Ahn, C.-Y. Correlations between environmental factors and toxic and non-toxic Microcystis dynamics during bloom in Daechung Reservoir, Korea. Harmful Algae 10, 188-193 (2011).

5. Kim, B., Kim, H.-S., Park, H.-D., Choi, K. \& Park, J.-G. Microcystin content of cyanobacterial cells in Korean reservoirs and their toxicity. Korean Journal of Limnology 32, 288-294 (1999).

6. Srivastava, A., Ahn, C.-Y., Asthana, R.K., Lee, H.-G. \& Oh, H.-M. Status, Alert System and Prediction of Cyanobacterial bloom in South Korea. BioMed Research International, Article ID 584696, http://dx.doi.org/10.1155/2015/584696 (2015).

7. Lee, Y., et al. Development of a water quality index model for lakes and reservoirs. Water Environ 12, S19-S28 (2014).

8. Park, H.-K., Jheong, W.-H., Kwon, O.-S. \& Ryu, J.-K. Seasonal succession of toxic cyanobacteria and microcystins concentration in Paldang Reservoir," Algae 15, 29-35 (2000). 
9. Joung, S.-H., et al. Water quality and cyanobacterial anatoxin-a concentration in Daechung reservoir. Korean Journal of Limnology 35, 257-265 (2002).

10. Cho, D.-H., et al. Characteristics of Water Quality in Wangsong Reservoir and Its Inflow Streams. Journal of Korean Society of Water and Wastewater 26, 201-208 (2012).

11. Jung, S., et al. The effect of phosphorus removal from sewage on the plankton community in a hypertrophic reservoir. Journal of Ecology and Environment 40, 1-9 (2016).

12. Carmichael, W.W. A review. Cyanobacteria secondary metabolites- the cyanotoxins. $J$. Appl. Bacteriology 72, 445-459 (1992).

13. Omidi, A., Esterhuizen-Londt, M. \& Pflugmacher, S. Still challenging: the ecological function of the cyanobacterial toxin microcystin - What we know so far. Toxin Reviews http://dx.doi.org/10.1080/15569543.2017.1326059 (2017).

14. Kim, S.-G., et al. Determination of Cyanobacterial diversity during algal blooms in Daechung Reservoir, Korea, on the basis of cpcBA intergenic spacer region analysis. Applied and Environmental Microbiology 72, 3252-3258 (2006).

15. Amé, M., et al. Microcystin-LR, -RR, -YR and -LA in water samples and fishes from a shallow lake in Argentina. Harmful Algae 9, 66-73 (2010).

16. Chen, J. \& Xie, P. Microcystin accumulation in freshwater bivalves from lake Taihu, China, and the potential risk to human consumption. Environmental Toxicol. Chem. 26, 1066-1073 (2007).

17. Chislock, M.F., Doster, E., Zitomer, R.A. \& Wilson, A.E. 2013. Eutrophication: causes, consequences, and controls in aquatic ecosystems. Nature Education Knowledge 4, 10. 
18. El Ghazali, E., et al. Effects of the microcystin profile of a cyanobacetrial bloom on growth and toxin accumulation in common carp Cyprimus carpio larvae. J. Fish Biol. 76, 1415-1430 (2010).

19. Herrera, N., Echeverri, L. \& Ferrão-Filho. S. Effects of phytoplankton extracts containing the toxin microcystin-LR on the survival and reproduction of cladocerans. Toxicon 95, 38-45 (2015).

20. Li, X.-Y., Chung, I.-K., Kim, J.-I. \& Lee, J.-A. Subchronic oral toxicity of microcystin in common carp (Cyprinus carpio L.) exposed to Microcystis under laboratory conditions. Toxicon 44, 821-827 (2004).

21. Pflugmacher, S., Amé, M., Wiegand, C. \& Steinberg, C. Cyanobacterial toxins and endotoxins their origin and their ecophysiological effects in aquatic organisms. Wasser Boden 53, 15-20 (1999).

22. Pflugmacher, S., et al. Uptake, effects, and metabolism of cyanobacterial toxins in the

23. Pflugmacher, S. Possible allelopathic effects of cyanotoxins, with reference to microcystin-LR, in aquatic ecosystems. Environ. Toxicol. 17, 407-413 (2002).

24. Babica, P., Bláha, L. \& Marsalek, B. Exploring the natural role of microcystins - A review of effects on photoautotrophic organisms. J. Phycology 42, 9-20 (2006).

26. Törökné, A. K., et al. Water quality monitoring by Thamnotoxkit F $^{\mathrm{TM}}$ including cyanobacterial blooms. Water Science and Technology 42, 381-385 (2000). 
27. DeMott, W. R., Zhang, Q.-X. \& Carmichael W. W. Effects of toxic cyanobacteria and purified toxins on the survival and feeding of a copepod and three species of Daphnia Limnol. Oceanogr. 36, 1346-1 357 (1991).

28. Kós, P., Gorzó, G., Surányi, G. \& Borbély, G. Simple and efficient method for isolation and measurement of cyanobacterial hepatotoxins by plant tests (Sinapis alba L.). Anal Biochem. 225, 49-53 (1995).

29. Stanier, R. Y., Kunisawa, R., Mandel, M. \& Cohen-Bazire, G. Purification and properties of unicellular blue-green algae (Order Chroococcales). Bacteriol. Rev. 35,

34. US EPA Methods for measuring the acute toxicity of effluents to freshwater and marine 

Protection Agency, EPA/600/4-85/013 (1985).

35. ASTM Standard Guide for Acute Toxicity Test with the Rotifer Brachionus. Method E1440-91 Reapproved 1998 (1998).

36. Kyselková I., \& Maršálek, B. Using of Daphnia magna, Artemia salina and Tubifex tubifex for cyanobacterial microcystins detection. Biologia 55, 637-643 (2000). angiosperms during ageing. Aquat. Bot. 12, 345-354 (1982).

356 
358 This research was in part supported by the National Research Foundation of Korea Grant 359 funded by the Korean Government (MISP) (2013, University-Institute Cooperation Program) 360 and the Korean Institute of Science and Technology (KIST) Institutional Program (2E24280). 361 The authors also wish to thank Mr J. Anton (Technische Universität Berlin) and Ms S. Kuehn 362 (Technische Universität Berlin) for technical assistance. 
Figure titles:

365

366 Figure 1: Cyanobacterial toxin composition of the $M$. aeruginosa KW strain isolated from

367 Wangsong reservoir (South Korea). Data represent mean toxin concentration \pm standard 368 deviation $(n=4)$

369

$370 \quad$ Figure 2: Oxidative stress response monitored as changes in cellular $\mathrm{H}_{2} \mathrm{O}_{2}$ level 371 in three submerged macrophytes: C. demersum (A), L. sessiliflora (B) and $P$. 372 perfoliatus $(\mathbf{C})$ during 14-day exposure to cyanobacterial cell-free crude extract 373 containing $50 \mu \mathrm{g} \mathrm{L}^{-1}$ total MCs. Data represent average $\mathrm{H}_{2} \mathrm{O}_{2}$ content \pm standard 374 deviation $(\mathrm{n}=3) ; *$ denotes statistical significance compared to the control $(\mathrm{p}>$ $375 \quad 0.05)$ 
377 Table 1: $\mathrm{LC}_{50}, \mathrm{EC}_{50}$ and $\mathrm{IC}_{50}$ of extract using various bioassays

\begin{tabular}{|c|c|c|c|c|}
\hline Bioassay & Test organisms & $\begin{array}{c}\text { Trophic } \\
\text { level }\end{array}$ & $\begin{array}{l}\text { Test outcome } \\
\left(\mathrm{LC}_{50}, \mathrm{EC}_{50},\right. \\
\left.\text { IC }_{50} *\right)\end{array}$ & 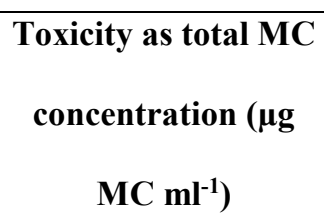 \\
\hline THAMNOTOX-FTM & $\begin{array}{c}\text { Thamnocephalus } \\
\text { platyurus }\end{array}$ & $\begin{array}{l}\text { Primary } \\
\text { consumer }\end{array}$ & 24-h LC 50 & $0.1 \pm 0.2$ \\
\hline ROTOTOX-F & $\begin{array}{l}\text { Brachionus } \\
\text { calyciflorus }\end{array}$ & $\begin{array}{l}\text { Primary } \\
\text { consumer }\end{array}$ & 24-h EC 50 & $6.5 \pm 1.2$ \\
\hline DAPHTOX pulex & Daphnia pulex & $\begin{array}{l}\text { Primary } \\
\text { consumer }\end{array}$ & 24-h EC 50 & $1.1 \pm 0.5$ \\
\hline TUBIFEX TOX & Tubifex tubifex & Detritivore & 24-h $\mathrm{EC}_{50}$ & $1.5 \pm 0.7$ \\
\hline ALGALTOX & $\begin{array}{c}\text { Pseudokirchneriella } \\
\text { subcapitata }\end{array}$ & $\begin{array}{l}\text { Primary } \\
\text { producer }\end{array}$ & 72-h EC 50 & $3.7 \pm 1.2$ \\
\hline РНҮтОТОХ & $\begin{array}{c}\text { Sorghum saccharatum } \\
\text { Sinapis alba }\end{array}$ & $\begin{array}{l}\text { Primary } \\
\text { producers }\end{array}$ & $\begin{array}{l}\text { 72-h } \mathrm{IC}_{50} \\
72-\mathrm{h} \mathrm{IC} \\
50\end{array}$ & $\begin{array}{l}3.4 \pm 0.5 \\
4.4 \pm 0.9\end{array}$ \\
\hline & Lepidium sativum & & 72-h IC 50 & $3.9 \pm 1.2$ \\
\hline
\end{tabular}

$* \mathrm{LC}_{50}=$ lethal concentration, $\mathrm{EC}_{50}=$ effect concentration, $\mathrm{IC}_{50}=$ inhibitory concentration 
Table 2: Altered morphology of macrophytes exposed to cyanobacterial cell-free crude extract 381 containing MCs at a concentration of $50 \mu \mathrm{g} \mathrm{L}^{-1}$ for 14 days

\begin{tabular}{|c|c|c|c|}
\hline & Ceratophyllum demersum & Limnophila sessiliflora & Potamogeton perfoliatus \\
\hline \multicolumn{4}{|l|}{ Control } \\
\hline \multicolumn{4}{|l|}{ MCs } \\
\hline \multicolumn{4}{|l|}{ exposure } \\
\hline$(50 \mu \mathrm{g}$ & & & \\
\hline $\left.\mathrm{L}^{-1}\right)$ & & & \\
\hline & & & \\
\hline
\end{tabular}

